\title{
'n Prakties-teologiese evaluering van moontlike bedieningstrukture in die Nederduitsch Hervormde Kerk toegespits op die rol van die predikant
}

TFJ Dreyer

\begin{abstract}
A practical theological evaluation of potential structures of ministry within the Nederduitsch Hervormde Kerk, focused on the role of the minister

Die modern society in which the church has to fulfill its ministry, differs in many aspects from the traditional society. The question arises whether the old pattern of ministry is still sufficient to accommodate new trends. This paper is an attempt to identify and establish alternative structures. This is done by means of investigating and exploring scriptural perspectives on church ministry. Certain alternative models are weighed against biblical findings and modem concepts. Finally, a revised pattern of ministry is proposed.
\end{abstract}

\section{MOTIVERING TOT DIE ONDERSOEK}

Binne die geledere van die Hervormde Kerk is die noodsaaklikheid van so ' $n$ ondersoek reeds op baie terreine van die kerk se werk intuïtief aangevoel. Op talle wyses manifesteer die vraag homself of die huidige wyse van kerklike bediening nog 'effektief' is in ons moderne tyd. Is die kerk nie dalk as gevolg van 'n argaïese bedieningspatroon besig om homself uit te rangeer tot ' $n$ randverskynsel van die samelewing nie?

In 'n studiestuk (Nederduitsch Hervormde Kerk $1985=$ NHK 1985) wat gedien het voor die Algemene Kerkvergadering van 1986, word die noodsaak van 'n ondersoek na bedieningstrukture duidelik verwoord. Verskeie fasette van die probleem word aangedui.

* Referaat gelewer voor die Hervormde Teologiese Vereniging by die Universiteit van Pretoria op 10 Junie 1987. 
Die stad sal nou en in die toekoms by uitstek sy werkterrein wees .... Die kerk het aanvanklik die stad met 'n plattelandse bedieningspatroon betree .... Die ontwikkeling van ' $n$ doeltreffende stedelike patroon kan nie langer uitbly nie (NHK 1985: 77).

Van evangelisasie ... het daar tot dusver weinig tereg gekom. Dit is grotendeels te wyte aan die feit dat dit alles oorgelaat is in die hande van 'n paar ampsdraers .... Dit lê voor die hand dat die gemeentelede as sodanig meer betrokke moet raak by hierdie arbeid (NHK 1986: 85).

Om genoemde tot sy reg te laat kom sal vra dat die dikwels eensydige klemlegging op die pastoraat verskuif na 'n gebalanseerde benadering waar deurlopende toerusting ook sy regmatige plek sal kry. Dit vra 'n voortdurende herevaluering van die predikant se taak in die gemeente (NHK 1985: 87).

Die kerk sal egter in sy evaluasie van die moontlikhede ruimte moet laat vir diversiteit en verskeidenheid van behoefte en omstandighede. Groter ruimte en vryheid sal mettertyd na gelang van die omstandighede gebied moet word sodat die kerk nie deur orde-reëlings en reglemente gekniehalter word nie (NHK 1985: $88)$.

Die verslag berus op gegewens verkry uit die staatsensus van 1980 waaruit blyk dat 81 persent van alle Hervormde lidmate in stedelike of semi-stedelike gebiede woon. Uit hierdie sosio-demografiese profiel blyk ook dat 21,4 persent van die kerk se lidmate, in vergelyking met die kerksensus, nie meer op die kerk se boeke vermeld word nie, wat daarop dui dat 'n groot aantal lidmate nie meer deur die kerk se bediening bereik word nie. Die statistieke toon ook aan dat die groeipotensiaal van die kerk uit eie geledere ernstig beperk is (NHK 1985: 76), wat die dringendheid van evangelisasie as groeipotensiaal van die kerk onderstreep.

Teen die agtergrond van hierdie gegewens is besluit om ' $\mathrm{n}$ kommissie te benoem om 'n ondersoek te doen na bedieningstrukture wat beantwoord aan die eise van omstandighede. Die verslag van die kommissie word nog afgewag. Die vraag oor bedieningstrukture is egter deur hierdie besluit op die agenda van menige raad en liggaam binne die kerk geplaas. Die versoek van die Hervormde Teologiese Vereniging om by hulle jaarlikse kongres oor dié onderwerp te handel, is ' $n$ bewys dat die kerk op verskillende vlakke besig is om oor bedieningstrukture te besin. Die versoek van die Hervormde Teolo- 
giese Vereniging was eerder toegespits op die funksie van die predikant binne moontlike nuwe strukture, daarom sal hierdie studie juis daarop gerig wees.

\section{METODE VAN ONDERSOEK}

Wanneer daar gevra word na ' $n$ prakties-teologiese evaluering van bedieningstrukture, moet daar 'n wetenskaplike ondersoekmetode aangedui word. Hiermee word die prakties-teologiese vraag na die verhouding tussen teorie en praxis op die voorgrond geplaas. Hoe word 'n teologiese teorie gevorm en in hoeverre het die praktyk 'n konstituerende bydrae tot die teorievorming te lewer? In sy teorievorming sal die Praktiese Teologie hom moet oriënteer

$\ldots$ aan die heersende teologiese oorlewering in die lig van die historiese ontwikkeling van die oorlewering èn aan die insigte wat empiriese analises oplewer. Met die twee kennisbronne stel ons nie die Skrif en die praktyk van die gemeente gelyk nie. Daar is ' $n$ kwalitatiewe verskil. Die Skrif is openbaringsbron en die praktyk van die gemeente 'n kennisbron vir die verfyning van die praktyk (Pieterse 1985: 3).

Die teologie (die historiese ontwikkeling is by die begrip teologie inbegrepe) en die empirie vorm dus die twee kennisbronne vir die teorievorming. Die mees gangbare opvatting in die verhouding tussen die twee pole, is die van 'n ellips met twee brandpunte, naamlik teologie en empirie (praxis). Hierdie twee pole verkeer in ' $n$ verhouding van kritiese wisselwerking sonder dat die een meer gesaghebbend of konstitutief is as die ander (Heitink 1979: 75-81). In so 'n benadering dreig die wesenlike gevaar dat die praxis so voorskriftelik kan raak, dat dit die teologiese norme oorskry of selfs afskryf.

'n Teologiese metode wat beter verantwoordbaar is, blyk dus te wees een waarin die kritiese wisselwerking (die teologie) steeds die konstitutiewe voorrang sal moet geniet. Die vraagstelling vanuit die empiriesanalitiese resultate sal vanuit die teologiese norme krities geëvalueer moet word. Slegs in die mate waarin die vraagstelling van die praxis teologies geakkommodeer kan word, kan dit ook medekonstitutief wees vir die uiteindelike teorievorming. Daar word dus gekies vir ' $n$ werkswyse waarin ons eers sal probeer vasstel watter teologiese gegewens as normatief kan geld. Daarna sal gekyk word na die vraagstelling van 'n 
empiries-analitiese ondersoek, om dan uiteindelik te kom by 'n teorievorming wat vanuit teologiese norme die praxis sal integreer. Enkele nuwe en/of aangepaste bedieningstrukture wat aangebied word, sal dan aan die hand van die teorie geëvalueer word en ten slotte sal 'n poging tot 'n moontlike bedieningstruktuur, toegespits op die predikant, aangebied word.

\section{TEOLOGIESE KRITERIA TEN OPSIGTE VAN BEDIENINGSTRUKTURE}

In 'n poging om teologiese kriteria te vind wat van belang is vir die bedieningstrukture kan 'n omvattende eksegeties-teologiese ondersoek verg. Binne die bestek van hierdie ondersoek is dit nie moontlik nie. Ons sal dit beperk tot ' $\mathrm{n}$ paar basiese riglyne om as basis vir die ondersoek te dien.

\subsection{Begripsbepaling}

Die begrip 'bediening' word in 'n omvattende betekenis gebruik as aanduiding van die oordra van die totale heil van God in Jesus Christus.

Dit is God wat in sy groot liefde vir'n gevalle mensheid optree en die inisiatief neem (Joh 3: 16). Enige vorm van bediening het dus sy oorsprong in God self. Jesus Christus voer die bediening uit wat 'n bediening van die versoening is (2 Kor 5: 18-19). Na sy hemelvaart sit Jesus Christus sy bediening voort in en deur sy kerk, deur die werk van die Heilige Gees. Die Heer het 'n rykdom van gawes en bedieninge aan sy kerk gegee. Gawes (charismata) en bedieninge is onderling verweef (Pieterse 1981: 75). As ons dus praat oor bediening, het ons daarmee in die oog die verantwoordelikheid van die kerk van Jesus Christus om hierdie versoening in al sy fasette te bedien.

Met 'strukture' word gedui op die wyse waarop die kerk se werksaamhede georganiseer word om as kanale te dien vir die genoegsame funksionering van die kerk om hierdie versoening te bedien. Die gemeente trag dus om sy doelstellinge te bereik deur sy bedieningstrukture, dit is die organisasie van sy gesagstruktuur (ampte, kerkleiding), sy kommunikasiestruktuur en die inrigting van die deelname van mense aan sy aktiwiteite (Pieterse 1981: 75).

Die vraag wat by hierdie begripsbepaling na vore kom, is of die strukture slegs 'n saak van formeel praktiese belang is, en of daar ook 
teologiese kriteria geld vir die strukture waarbinne die bediening moet plaasvind. Op die oog af mag dit lyk of bediening te doen het met die teologiese begronding terwyl strukture gewoon berus op die eise van die praktyk. Die struktuur of vorm van die bediening kan egter nie by voorbaat afgeskryf word as 'n saak wat gewoon op grond van praktiese eise en omstandighede uitgemaak word nie. Ons sal ook moet probeer bepaal in hoeverre daar teologiese kriteria geld ten opsigte van die vorm en struktuur van die bediening.

\subsection{Riglyne vanuit die Skrif}

Dit is uit die aard van die saak onmoontlik om binne die kader van hierdie ondersoek 'n volledige eksegetiese studie te onderneem. Ons wil hier volstaan met enkele riglyne vanuit die Skrif wat lig kan werp op die vraag na bedieningstrukture. As uitgangspunt geld ook dat 'n vraag aan die Skrif gestel word waarop die Skrif nie per se 'n antwoord sal verstrek nie, omdat die vraag na bedieningstrukture nie binne die primêre skopus van die Skrif staan nie. Sonder om Bybelse gegewens te oorspan, wil ons gewoon gaan soek na gegewens wat lig kan werp op die vraagstelling.

\subsubsection{Die bediening as opdrag aan die kerk}

Jesus Christus is die grond van die bediening (2 Kor 5: 18-19; 2 Kor 4: 10-11; 2 Kor 5: 14). Die mees omvattende begrip wat hierdie bediening aandui is 'diakonia'. Dit lê klem op die betekenis van 'diens', 'dien', 'dienaar' in teenstelling met die begrip 'amp', wat kan lei tot wanopvattings, omdat dit weer die klem lê op gesag in plaas van diens. 'Die Bybelse studies dui almal in hierdie rigting: die een grondliggende bediening is die van Christus; en hy voer dit uit deur sy Kerk' (Kritzinger 1979: 150). Daar is dus slegs een bediening van Christus wat die kerk as sy liggaam moet uitvoer. 'Dit druis in teen die Bybelse begrip van die Kerk as hierdie bediening en taak die voorreg sou word van net 'n groepie in die kerk' (Kritzinger 1979: 150). Veral die beeld van die kerk as liggaam (1 Kor 12) maak dit duidelik dat elke afsonderlike lid 'n noodsaaklike rol speel in die funksionering van die liggaam. 'Die sogenaamde "leek" is 'n latere skepping. Elke gelowige moet inderdaad sy priesterskap uitleef' (Kritzinger 1979: 151).

\subsubsection{Besondere bedienings}

Ten opsigte van die vraag na besondere bediening kan Efesiërs 4: 7-11 as uitgangspunt geneem word, waaruit duidelik blyk dat God ook 
binne die gemeente, buiten die algemene roeping wat as gawe gegee is, ook onderskeibare gawes gee met die funksionele doel die toerusting van die gelowiges tot die dienswerk in die wêreld. Roberts (1963) toon dit in sy proefskrif duidelik aan dat die een oorkoepelende taak van die besondere bediening dié van toerusting is. Kritzinger (1979: 155-158) maak ' $n$ saak daarvoor uit dat die metodes wat hierdie besondere dienste gebruik om die ander toe te rus, is deur middel van hulle voorbeeld; deur te onderrig; deur te dien en deur die sakramente. Die besondere bedieningswyses is dus 'n funksionele verdeling, wat nie die algemene bediening vervang of oorbodig maak nie, maar juis daarop afgestem is om die gelowiges toe te rus vir hulle bediening in die wêreld tot opbou van die liggaam van Christus.

\subsubsection{Bediening en gawes}

Vanuit Bybelse gegewens is dit duidelik dat daar 'n noue samehang is tussen gawes en bediening. Charisma en amp staan nie teenoor mekaar nie, maar is onderling verweef op 'n funksionele vlak. Die volgende Skrifgedeeltes handel in die besonder oor dié saak, naamlik Romeine 12: 7-8; 1 Korintiërs $12-14$ en Efesiërs 4: 11. Kritzinger (1979: 169) maak op grond van genoemde gedeeltes die volgende opmerkings:

- Elke Christen ontvang een of meer gawes wat hom/haar in staat stel om die spesifieke taak (diens) wat God aan hom/haar opgedra het, te kan uitvoer.

- Gevolglik ontvang nie alle Christene dieselfde gawes nie. Hulle take is aanvullend en so ook die gawes.

- Al die gawes word gegee vir die wedersydse opbou van die liggaam van Christus.

- Elkeen, of hy apostel, profeet, leraar of enigiets anders is, het die taak om te dien, elkeen op sy besondere terrein, met gebruikmaking van die gawes wat God daarvoor gegee het. Elkeen se bediening is noodsaaklik vir die totale bediening.

- Elkeen het ook nie ewe veel ontvang nie. Die Gees deel sy gawes uit soos wat $\mathrm{Hy}$ wil en soos wat Hy weet dit nodig is.

- Die gawes word nie gegee vir persoonlike ekstase en bevrediging nie, maar vir die bediening.

- Daar is ook 'n verantwoordelikheid wat met die gawe gepaard gaan. God verwag dat die gawes benut word.

Die funksionele onderskeiding van die bediening is dus nie 'n saak van 
persoonlike willekeur nie, maar hang ten nouste saam met die gawes wat God gee, om uiteindelik die bediening moontlik te maak.

\subsubsection{Bediening as diens}

Die dienskarakter van die bediening is van so 'n deurslaggewende betekenis vir die kerklike bediening, dat dit prominent na vore moet kom onder 'n aparte opskrif. Jesus is self die volmaakte voorbeeld van die aard en karakter van hierdie diens (Matt 10: 28; Mark 10: 45; Fil 2: $5-8)$. Die kerklike bediening in al sy vorme kan dus nooit ' $n$ ander karakter hê as die dienskneggestalte van Jesus nie. Dit sluit nie die moontlikheid van sterk leierskap en outoriteit uit nie, maar outoriteit is slegs geldig wanneer dit gebaseer is op diens en nie op voorregte, regte en mag nie. Met hierdie tipering van bediening as liefdesdiens word elke sweem van 'n strewe na status, aansien en outoriteit in sy wese vernietig.

\subsubsection{Strukture en vorme}

Die oomblik wanneer vrae rakende die vorme en strukture aan die Nuwe Testament gestel word, loop die ondersoeker hom vas teen 'n vloeibare situasie sonder vaste omlynings. Bolkestein (1961: 35-36) dui op die groot verskil in die gemeente-organisasies in die geskrifte van Johannes en die Pastorale Briewe. By Johannes heers 'n groot mate van vryheid, terwyl die orde in die Pastorale Briewe voorop staan. Die Pastorale Briewe gee blyke van organisasie teen die dwaalleer. Johannes korrigeer weer die gevaar van 'n sakrale kerk. Die briewe van Paulus en enkele gegewens in Handelinge (14: 23) dui ook op 'n ander patroon as die van Timoteus en Titus. In Korinte het skynbaar die eenvoudigste organisasie ontbreek; selfs die aanduiding van verkose ouderlinge ontbreek. Filippi was skynbaar 'n meer georganiseerde gemeente, want daar is sprake van 'n tweërlei vorm van amptenare, naamlik opsieners en diakens (Fil 1: 1) (Kritzinger 1979: 178). Vanuit die gegewens van die briewe van Paulus sal hoogstens die afleiding gemaak kan word dat daar in elke gemeente die een of ander vorm van organisasie was, wat na gelang van omstandighede verskil het, en dat sekere ampte gefunksioneer het wat verskillend aangedui word.

Kritzinger (1979: 178-181) bevind in sy ondersoek dat vanuit Skrifgegewens daar hoogstens 'n paar beginsels ten opsigte van vorm en struktuur as kriteria kan geld. 
- Daar is ' $n$ duidelike ontwikkeling ten opsigte van organisasie en struktuur waarneembaar, wat die beginsel van aanpassing in elke situasie verdiskonteer.

- Die ontwikkeling in struktuur is altyd funksioneel van aard. Die primêre vraag is nie of dit 'n Bybelse patroon is nie, maar of dit in 'n bepaalde situasie die bediening van die gemeente bevorder of belemmer.

- Die bediening is blywend en daarom moet die beginsel van verandering nie die indruk skep dat met die besondere bediening weggedoen kan word nie.

Samevattend blyk dit dat die plaaslike gemeente georganiseer was rondom ten minste sekere ampte of bedieninge wat verskillende inhoude en aksente gehad het, na gelang van die eise van die omstandighede.

\subsubsection{Die tentmakerbediening}

In die huidige bedienigspatroon word daar algemeen gewerk met die predikant as iemand wat ' $n$ voltydse bediening beklee. Teenswoordig word weer stemme gehoor ten gunste van die sogenaamde tentmakerbediening. Die tentmakerbediening verskil in die opsig van dié van 'n voltydse predikant dat hy net 'n gedeelte van sy werkstyd aan sy bediening wy en tegelyk ' $n$ ander betrekking beklee wat hom gedeeltelik of totaal van sy lewensonderhoud voorsien.

Dit is vreemd aan die Nuwe Testament om aan die bediening te dink as die aktiwiteit van 'n groep professionele mense. Die optrede van Jesus en sy dissipels was in 'n sekere sin 'n uitdaging aan die professionele priesterklas en hulle medestanders (Kritzinger 1979: 182). Rondom die figuur van Paulus kan sekere afleidings gemaak word. Hy was tegelyk 'n geskoolde rabbynse student en opgelei in handewerk, naamlik tentmakery. Hy stel dit (1 Kor 9: 7, 14; 1 Tim 5: 17-18) dat die apostel wat voluit die evangeliebediening behartig, 'n reg het op onderhoud deur die gemeente. Tog het Paulus bewustelik by geleentheid van hierdie reg afstand gedoen (1 Kor 9: 12, 15) en vir sy lewensonderhoud teruggeval op sy tentmakersambag (Hand 18: 2-4; 20: 33-34; 1 Tess 2: 9). Jesus stuur sy dissipels uit met die opdrag dat hulle die werk van die evangelie moet verrig, sonder om iets te vra (Matt 10: 8), maar andersyds moet hulle ook geen geld of kos saamneem nie, want ' $n$ arbeider is tog geregtig op onderhoud (Matt 10: 10). Daar blyk dus 'n mate van spanning tussen die twee aspekte te wees. Paulus se optrede getuig daarvan dat hy nie vir die gemeente 'n las wil wees 
nie (2 Tess 3: 8; 2 Kor 11: 20), maar ook aan hulle 'n voorbeeld wou stel (1 Kor 4: 12, 16), terwyl hy tog by geleentheid hulp aanvaar (Fil 4: 10).

Hierdie losse verskeidenheid het lank voortgeduur. In die vroeë kerk het die siening blykbaar ontstaan dat die geestelike bediening en ' $n$ sekulêre beroep nie kan saamgaan nie. Vischer (1965) gee 'n goeie oorsig van die ontwikkeling van die tentmakerbediening. Vir die doel van hierdie ondersoek is alleen van belang om op te merk dat beide die tentmakerbediening en die reg op onderhoud, erkenning geniet.

\subsubsection{Samevatting van Skrifgegewens}

As die basiese riglyne vir bedieningstrukture vanuit die Skrif neergelê word, kan die volgende as kriteria geld:

- Die inhoud en grond van die bediening is Jesus Christus.

- Die bediening is as opdrag aan die kerk as geheel toevertrou.

- Daar is te onderskei in besondere bedienings op grond van gawes en funksies.

- Besondere bedienings het altyd ten doel die toerusting van gelowiges vir hulle algemene bediening.

- Bediening en gawe is onafskeidbaar.

- Bediening word gekarakteriseer deur die dienskneggestalte van Christus.

- Rondom die basiese gawes en bedienings is vorm en strukture aanpasbaar na gelang van omstandighede.

- Die tentmakerbediening is ' $n$ erkende vorm van bediening.

\subsection{Riglyne vanuit die teologiese tradisie}

Aanvanklik is gestel dat die een komponent van die prakties-teologiese teorievorming die teologie is. Met teologie word dan bedoel die gegewens vanuit die Skrif, maar ook die teologiese ontwikkeling van hierdie Skrifwaarhede deur die teologiese arbeid van die kerk deur die eeue. In hierdie opsig is daar 'n ryk en lang teologiese tradisie waaruit geput kan word. In die teologiese denkarbeid van die kerk is daar ook 'n duidelike ontwikkelingslyn in die geskiedenis waarneembaar, met veral die teologiese denke van die kerkhervorming as belangrike baken. Dit is egter 'n omvangryke en waarskynlik ook 'n onbegonne taak om die geskiedenis en ontwikkeling van die teologiese tradisie tot op datum aan te dui. ' $n$ Ander moontlike werkswyse is om gewoon die neerslag van die teologiese tradisie in die Kerkwet en Bepalings as 
vertrekpunt te neem - in afgeleide sin is kerkregtelike bepalings die stolling van sy teologiese denke op 'n bepaalde tyd. Bloot ter wille van praktiese oorwegings wil ons laasgenoemde werkswyse volg om vanuit die Kerkwet van die Nederduitsch Hervormde Kerk (NHK 1986) sekere teologiese lyne te trek.

\subsubsection{Die roeping van die Kerk}

Die bediening van die kerk word deels verwoord in Artikel IV van die Kerkwet wat die roeping van die kerk beskryf (NHK 1986: 1):

1. Die opdrag van Christus aan sy kerk is om
(a) die Woord van God aan alle mense te verkondig;
(b) die sakramente te bedien;
(c) eredienste te hou en te bid;
(d) barmhartigheid te bewys;
(e) die naam van God in die openbaar te bely;
(f) teenoor owerheid en volk te getuig;
(g) kategetiese onderrig te gee;
(h) herderlike sorg te verrig;
(i) opsig te hou oor die leer en lewe van gemeentes, ampsdraers en lidmate en tug uit te oefen;
(j) medeverantwoordelik te wees vir die Christelike opvoeding van die kinders van die kerkvolk;
(k) dienaars van die Woord op te lei en te vorm;
(l) teologiese arbeid te verrig, en
(m) die algemeenheid en eenheid van die kerk wat geopenbaar word oral waar Christus geheel en alleen as Heer en Saligmaker bely word, openlik te bely en te beleef.

Dit is meteen duidelik dat die kerk hier die bediening van Christus teologies geïnterpreteer en verfyn het in verskillende fasette waarin die bediening na vore kom. Opmerklik is dat die kerk hier sy teologiese opleiding en arbeid verhef tot deel van die roeping van die kerk, wat wesenlik nie deel is van sy roeping nie, maar in afgeleide sin die gevolg is van sy roeping. In geheel beskou, blyk hierdie teologiese verfyning van die bediening as opdrag, in lyn te wees met die gegewens vanuit die Skrif.

\subsubsection{Die ampte}

Die verskeidenheid van die bedieninge het die kerk in sy teologiese denke gereduseer tot die ampte. In Artikel V word die ampte soos volg omskryf (NHK 1986: 2): 
1. Om Christus se opdrag aan die kerk te vervul en om in die verskeidenheid van dienste te voorsien, is daar drie ampte, naamlik die amp van

(a) dienaar van die Woord;

(b) ouderling, en

(c) diaken.

2. Dienaars van die Woord word onderskei in

(a) predikante, en

(b) professore en ander dosente in die teologie.

3. Die gemeente verkies en roep ampsdraers en meerdere vergaderings met die bevoegdheid daartoe verkies en wys ampsdraers aan volgens die opdrag van Christus aan sy kerk.

4. Ampsdraers word in 'n erediens met gebruikmaking van die betrokke formuliere uit die Kerkboek bevestig.

Die soepelheid wat ons in die gegewens van die Nuwe Testament rondom gawes en bedieninge vind, word hier op 'n formele wyse saamgebundel in die drie ampte. In die verdere uitwerking van die inhoud van hierdie ampte in die bepalings van die Kerkwet blyk die volgende ten opsigte van die predikant en ouderling:

\subsubsection{Die predikant}

Die predikant se dienswerk word in Bepaling 149 omskryf en kan saamgevat word as:

- verkondiging van die Woord en bediening van die sakramente;

- lei van eredienste;

- 'amptelike' pligte soos die lei van vergaderings en bevestiging van ampsdraers;

- saam met die ouderlinge is die predikant ook verantwoordelik vir die pastoraat, kategese, jeugwerk en opsig.

Vanuit die beroepsbrief is dit ook duidelik en voor-die-hand-liggend dat die kerk die amp van predikant as 'n voltydse bediening beskou. In die uitwerking van die amp van predikant val die aksent duidelik op sy verkondigings- en versorgingstaak. Die aspek van die amp as toerusting van die gelowiges ontbreek geheel en al. 'n Mens kan wel die argument aanvoer dat toerusting by implikasie ingesluit is in die verkondiging in al sy gestaltes. Vanuit Bybelse perspektief het die aksent van die besondere gawes en bediening juis gelê op die toerusting. Dit wil lyk asof die kerk in sy teologie 'n verskuiwing toegelaat het 
vanaf toerusting na versorging. Hierdie aksentverskuiwing blyk ook uit die bevestigingsformulier vir die dienaars van die Woord. Die formulier werk primêr met die herderbeeld as aanduiding van die verantwoordelikheid van die herder teenoor sy kudde. Efesiërs 4: 11 en 12 word wel aangehaal as motivering vir die instelling van die herdersamp sonder om verder die amp as middel tot toerusting van gelowiges vir hulle dienswerk te aksentueer.

\subsubsection{Die ouderling}

Die arbeidsveld van die ouderling word nader omskryf in Bepaling 167. Die omskrywing kan saamgevat word as:

- opsig oor die leer en lewe van die predikant;

- opsig oor die leer en lewe van die gemeente;

- medeverantwoordelikheid vir die pastoraat, kategese, evangelisasie en jeugwerk.

Die klem val hier weer op opsig, regering en versorging, terwyl die amp as instrument tot toerusting nêrens direk ter sprake kom nie.

\subsubsection{Priesterskap van die gelowiges}

Die bediening as verantwoordelikheid van elke gelowige word vervat in Artikel VIII.

'Gelowiges is geroepe om hulle priesterskap te vervul en ampsdraers in hulle dienswerk by te staan' (NHK 1968: 3). Interessant is die verband wat hier gelê word tussen besondere en algemene amp, naamlik dat gelowiges die ampsdraers moet bystaan in hulle dienswerk. Dit is per afleiding eintlik die ampsdraers wat primêr die dienswerk moet verrig met bystand van alle gelowiges. Bybels gesien, behoort die onderlinge verhouding die omgekeerde te wees, naamlik dat ampsdraers die gelowiges moet toerus en bystaan om hulle dienswerk te verrig. In Bepaling 184, waar die priesterskap van die gelowiges fyner uitgespel word, lê die swaartepunt by die bewaring en instandhouding van die gemeente deur middel van erediensbywoning, offergawes, huisgodsdiens en voorbidding. Die verrigting van hulle dienswerk in die wêreld word slegs omskryf deur: '. . . met woord en daad voortdurend die evangelie te verkondig tot uitbouing van die kerk en die koninkryk van God . . barmhartigheid aan alle mense te bewys . .' (NHK 1986: 108). 


\subsubsection{Kerklike organisasie}

Wat die kerklike organisasie betref, omskryf die kerk dit soos volg:

Ter wille van die goeie orde word almal wat deur die genadeverbond tot die kerk behoort byeengebring in gemeentes. ' $n$ Gemeente is die verskyningsvorm van die kerk op elke aangewese plek ... (NHK 1986: 1).

In Bepaling 16-20 word die gemeente nader omskryf. Dit kan saamgevat word onder die volgende aspekte:

- Vanuit die verbond word 'n gemeente gevorm deur die doop en die aantal belydende lidmate binne 'n bepaalde geografiese gebied.

- Die gemeente verkies ampsdraers binne die wykstelsel en die ampsdraers vorm die kerkraad van die gemeente wat opsig uitoefen en regeer.

- 'n Gemeente wat so gevorm is, kan 'n predikant beroep om voltyds in hulle midde te werk, met die onderneming dat hulle hom sal versorg.

Hierdie vaste patroon van gemeentelike organisasie geld vir alle gemeentes, behalwe vir studentegemeentes wat nie noodwendig geografiese grense het nie. Hierdie parogiale sisteem word dus voorskriftelik vasgelê vir alle gemeentes, ongeag plaaslike omstandighede.

\subsubsection{Samevatting}

Met hierdie enkele kontoere van die neerslag van die teologie in die kerkorde kan 'n paar hoofsake opsommenderwys saamgevat word.

- Die kerk aanvaar die bediening van Jesus Christus as opdrag aan die kerk.

- Die verskeidenheid in 'n ampstruktuur manifesteer in drie onderskeie ampte.

- Inhoudelik is die amp van predikant primêr gerig op verkondiging en versorging.

- Inhoudelik is die amp van die ouderling primêr gerig op opsig, lering en versorging.

- Die algemene bediening van elke gelowige, toegerus deur die besondere ampte, geniet weinig aandag.

- Die kerklike organisasie op gemeentelike vlak is vasgelê in 'n territoriale/parogiale sisteem, onder opsig en regering van 'n kerkraad, met die predikant as voltydse bedienaar op koste van die gemeente. 


\section{VERKENNING VAN DIE PRAXIS}

Naas die komponent van die teologie, is die ander brandpunt in die ellips van die prakties-teologiese teorievorming, die praxis. Om die eise en omstandighede van die praktyk waarbinne die kerk sy bediening moet vervul, te verstaan, sal hierdie werklikheid aan empiries-analitiese ondersoek onderwerp moet word om tot gegronde wetenskaplike gegewens te kom.

Verskeie wetenskaplike ondersoeke vanuit sosiologiese, godsdienspsigologiese, kultuur-filosofiese en statistiese perspektief is al in dié verband gedoen.' $n$ Magdom materiaal en inligting is tot die beskikking van die kerk. Ons wil hier volstaan deur enkele knelpunte en die implikasies daarvan vir die kerklike bediening uit te wys.

\subsection{Verstedeliking}

'n Demografiese verskuiwing het ook binne die Hervormde Kerk plaasgevind vanaf die platteland na die stad. Die staatsensus van 1980 het aangetoon dat 81 persent van alle Hervormde lidmate in stedelike of semi-stedelike gebiede woon (NHK 1985: 75). Louw (1980: 41) maak'n saak daarvoor uit dat nie alleen die getalle-oorwig in die stede die probleem van die stadsmens binne stedelike gebiede binne die fokus van die kerk bring nie, maar dat ook die mense wat nog op die platteland woonagtig is, in 'n groot mate deurdrenk is met die gees van die stad. 'In 'n sekere sin is alle mense "stadsmense". Ook die "oom" op sy rustige boereplaas in die Karoo adem die atmosfeer van "die stad" in.' Die stad is 'n kwalitatiewe term, 'n gemoedstoestand, 'n gesindheid, 'n styl van lewe. As ons dus hier praat oor verstedeliking, het ons nie soseer die demografiese verskuiwing in die oog nie, maar die gees van die verstedelikte mens, wat hom selfs op die platteland manifesteer.

\subsection{Mobiliteit}

Baie mense het pendelaars geword tussen woonplek en werkplek. Vir vele stadsmense het die woonplek net 'n slaapplek geword waar slegs die vrye tyd, veral oor naweke, deurgebring word. Die grootste deel van sy tyd en aandag word by sy werkplek spandeer (Pieterse 1981: 77). Met sy vol program in die week en sy min tyd by sy huis leef hy vir sy 'af tye'. Dit veroorsaak dat hy in sy vrye tyd wegbreek van sy werkstruktuur en ook van sy gemeentestruktuur. Die naweek bied hom die geleentheid om weg te breek uit die stad en weer asem te skep (Louw 
1980: 64). Andersyds wil hy sy vrye tyd spandeer in die teenwoordigheid van sy gesin en vriendekring. Dit bring mee dat die kerk moeilik hierdie 'pendelaar' in sy beperkte vrye tyd by sy woonplek by kerklike aktiwiteite kan betrek.

Die mobiliteit van die moderne mens kom ook na vore in die feit dat hy voortdurend rondbeweeg van een werkgeleentheid na die volgende, wat veroorsaak dat hy en sy gesin voortdurend trek en dus nooit werklik gevestig raak binne 'n geografiese gebied en gemeenskap nie. Die kerk slaag nie daarin om met hierdie mobiliteit tred te hou en voortdurend sy lidmate op te spoor nie. Op dié wyse raak baie lidmate vir die kerk verlore. Die staatsensus van 1980 het aangetoon dat binne die Pretoria-gebied daar 12000 lidmate is waarvan die kerk nie weet nie (NHK 1985: 76). Hierdie probleem word vererger deur die feit dat die lidmate nie hulle verantwoordelikheid aanvaar nie, maar binne die bedieningspatroon opgevoed word tot 'n houding dat die kerk hom moet opsoek en versorg.

\subsection{Anonimiteit}

Die mens is een van die massa en hoewel hy vele kontakte met ander het, is dit beperk tot funksionele onpersoonlike kontak (Cox 1968: 51-62). Hy verkies dikwels die privaatheid en anonimiteit van sy woonplek en vir persoonlike kontak kies hy vriende by wie hy aanklank vind. Hierdie persoonlike kontak strek dikwels oor straatblokke en voorstede heen. Aan die ander kant bevry anonimiteit hom van en beskerm hom teen gedwonge, onpersoonlike kontak binne bepaalde strukture. Die mens neig om ook sy godsdiens te privatiseer (Dekker 1971: 26-36). Die godsdiens word afgebaken tot die terrein waarvoor dit relevant is, naamlik die private lewe, terwyl dit niks te maak het met sy lewe na buite in die sfeer van sy werk nie. Lidmate skakel alleen die kerk in, in soverre dit vir hulle funksioneel is. Hy wil nie sy privaatheid geskaad hê nie, hy ontwikkel 'n gedistansieerde deelname en wil sy kerklike kontakte kerklik-funksioneel hou (Alant 1972: 101).

Die eensame stadsmens het dikwels 'n behoefte aan meer ruimte om sy unieke persoonlikheid en vermoëns uit te leef. In sy institutêre oorgretigheid probeer die kerk dan die stadsmens binne die gemeenskap van gelowiges opvang, maar dit blyk dan 'n gemeenskap te wees waarin hy passief is (Louw 1980: 63). 


\subsection{Funksionaliteit}

Die mens het ' $n$ kritiese gees ontwikkel. Alles word gemeet aan die vraag: Werk dit? Wat nie funksioneel is nie, word afgeskryf. Die kerk word ook aan hierdie maatstaf gemeet.

'n Kerk wat net bestaan uit kollektelyste, dankofferkoeverte, basaartafels en laat kerkraadsvergaderings oor finansies, word gou bevraagteken. ' $n$ Tradisie en gewoonte godsdiens dien geen doel nie en word deur die stadsmens as ondoeltreffend afgeskryf (Louw 1980: 67).

\subsection{Mondigheid}

Die mondige mens het behoefte daaraan om inspraak te hê in die formulering van sy optrede en lotgevalle. Hy wil nie slegs meer outoritêr voorgesê word nie, maar saampraat en -dink oor sy lewe (Pieterse 1981: 78).

\subsection{Statistiese gegewens binne die Hervormde Kerk}

Uit 'n onlangse opname wat deur die Raad vir Prediking en Erediens in samewerking met die RGN gedoen is, kan ' $n$ bepaalde beeld gevorm word ten opsigte van die situasie binne die Hervormde Kerk.

- 65 persent van die gemeentes het 'n belydende lidmaattal van 500 of meer lidmate;

- 53 persent van die predikante sê dat dit nie vir hulle moontlik is om jaarliks by alle lidmate huisbesoek te doen nie;

- 90 persent van die lidmate verwag gereelde jaarlikse huisbesoek van die predikant.

- Daar is ' $n$ algemene gevoel van oorbelading ten opsigte van die besondere pastoraat.

- Predikante bestee gemiddeld die volgende aantal ure per week aan

- gesin: 10 uur;

- huisbesoek: 12-20 uur;

- preekvoorbereiding: 10-15 uur;

- kategese: 2 uur;

- ander gemeentelike pligte: 20 uur;

- sinodale werk: 2 uur.

- 60 persent van die lidmate beweer dat die prediking vir hulle lewe van elke dag sonder betekenis is. 
Uit hierdie gegewens blyk dit reeds duidelik dat in die huidige bedieningspatroon die getal lidmate per predikant te hoog is om hulle jaarliks almal te besoek. Die gemeente koester wel nog die verwagting van jaarlikse besoeke. Die besondere pastoraat verg steeds meer aandag van die predikant. Onder 'ander gemeentelike pligte', wat gemiddeld 20 uur per week van predikante in beslag neem, kan die afleiding gemaak word dat die predikant grotendeels belas is met allerlei orgaaisatoriese funksies wat deur gemeentelede self hanteer kan word.

\subsection{Samevatting}

Hierdie kursoriese verkenning van die werklikheid waarbinne die kerk sy bediening moet uitvoer, stel die volgende eise aan die kerk se bedieningstrukture:

- Die landelike gees het grotendeels plek gemaak vir die gees van die stadsmens en daarom sal die kerk nie meer kan volstaan met 'n struktuur wat veral toegespits is op ' $n$ landelike bediening nie.

- Indien die kerk suksesvol die lidmaat by sy woonplek wil betrek, sal dit nie noodwendig binne geografiese woongebied hoef te wees nie. Wyksverband bied nie meer die natuurlike en spontane groepskohesie nie.

- Die mens se strewe na privaatheid en ontvlugting in sy vrye tyd moet erken word.

- Gedwonge gemeenskapsbelewenis is nie die antwoord op vereensaming en anonimitiet nie.

- Funksionaliteit vra van die kerk dat die tyd wat hy van die lidmaat vra, doelgerig en sinvol ingerig moet word.

- Meer ruimte moet geskep word vir deelname en inspraak van lidmate.

- Groepvorming moet geskied rondom gesamentlike belange en aktiwiteite.

- Die taakomskrywing van die predikant en rolverwagting van die gemeente moet gesinkroniseer word.

- Toerusting van ampsdraers en lidmate vir hulle dienswerk vra meer aandag.

- Prediking moet lewensgetrou en konkreet wees.

- Kleiner gemeentes met meer intensiewe bearbeiding is noodsaaklik.

\section{OORSIG VAN ALTERNATIEWE BEDIENINGSTRUKTURE}

In die literatuur word verskeie alternatiewe of gemodifiseerde bedieningstrukture aangebied, wat eerder sou beantwoord aan die eise van 
die tyd. Sommige pleit vir geheel nuwe modelle, terwyl ander weer binne die bestaande model ander aksente lê. 'n Paar van die voorgestelde modelle sal kortliks bespreek en geëvalueer word.

\subsection{Kategoriale versus parogiale strukture}

Om hierdie twee modelle teen mekaar op te weeg, is dit nodig om eers 'n oorsig te gee van beide.

\subsubsection{Die parogiale of territoriale struktuur}

Die tradisionele struktuur is dié waar gemeentes gevorm word binne 'n bepaalde territoriale of geografiese gebied. Dit word ook die parogiale stelsel genoem. Parogie is die oorspronklike woord wat vir gemeente gebruik is. Elke parogie word versorg deur 'n eie plaaslike pastor en 'n eie plaaslike kerkraad. Gemeentelede mag hulle kerklike voorregte en versorging en hul dienswerk slegs binne die territorium van die plaaslike parogie beoefen. Hierdie struktuur word in die gereformeerde kerkreg as die normale gesien (Pieterse 1981: 82). Met die verstedeliking het 'n groot digtheid van mense binne 'n klein geografiese gebied ontstaan. Die antwoord van die kerk was om gemeentes af te stig met een leraar en 'n hanteerbare lidmaattal. Afstigting in die stad word later onmoontlik vanweë oorkapitalisering van kerkgeboue wat enkele blokke van mekaar staan. ' $n$ Klein gemeente kan nie finansieel die groot las dra nie.

Binne die parogiale struktuur is 'n verdere oplossing gesoek deur die aantal predikante per gemeente te vermeerder, die sogenoemde medeleraarskap. Dit ly tot 'n massale onpersoonlike karakter wat skadelik is vir die onderlinge koinonía en die aktivering van die gemeente.

Verwant aan die medeleraar-reëling is die wyse van strukturering waar 'n groot aantal leraars in een gemeente elk in één bedieningsaspek spesialiseer. Een sal byvoorbeeld die prediking behartig, 'n volgende die onderrig, ' $n$ ander die pastoraat, ens. In Amerika kom dit redelik algemeen voor, maar ook dit het hier nie inslag gevind nie (Pieterse 1981: 83).

Al die genoemde variasies berus nog steeds op die basiese beginsel van die parogie, naamlik dat 'n gemeente binne 'n bepaalde gebied saam gegroepeer word. As kritiek teen hierdie model wys Hoekendijk (1965: 92) daarop dat die geografies gebonde model ontwerp is om alleen in 'n 
stabiele samelewing te funksioneer en beslis nie vir die mobiele stad geskik is nie, omdat dit die mens slegs in een van sy wêrelde, naamlik sy woonplek, ontmoet.

\subsubsection{Kategoriale struktuur}

Kategoriale bediening wil aandui dat die bediening nie gestruktureer word rondom die geografiese woongebied nie, maar dat die bediening in die arbeidswêreld moet inbeweeg, tussen industriewerkers, sakemanne, studente ensovoorts. Die uitgangspunte is nie dat die persone behorende tot 'n sekere kategorie soveel gemeen het nie, maar dat hulle vanuit dieselfde situasie dieselfde vrae in die lig van die Woord wil stel (Pieterse 1981: 83). Greimacher (1966: 341) praat van funksionele gemeentes en wys daarop dat 'n geografiese gebied ook as 'n funksie (kategorie) beskryf kan word. In die kategoriale stelsel is verskillende kategorieë bepalend vir die vorming van gemeentes en die verdeling in groepe binne 'n gemeente. Ouderdom, geslag, beroep, belangstelling en situasie is almal faktore wat tot kategoriale groepering kan lei. Kategoriale bearbeiding bestaan reeds in Suid-Afrika in die vorm van studente, hospitaal, bejaarde en militêre bearbeiding. Genoemde kategoriale bearbeiding werk goed solank die soortgenote, soos in genoemde gevalle, ook op dieselfde plek woon. Wolfaardt (1971: 18-23) kom ook tot die gevolgtrekking dat gemeentevorming by die werksplek moeilik is, as dit nie ook saamval met die woonplek nie.

\subsubsection{Evaluering}

By die evaluering van die genoemde twee modelle moet die voor- en nadele van beide in oorweging geneem word. Pieterse voer tereg 'n hele aantal teologiese argumente aan waarom die parogiale model behou moet word (1981: 84-85). Die eerste argument is dat mense uit alle groepe deur geloofsbinding in 'n eenheid saamgesnoer word. Die saambinding in die parogiale gemeente is dus juis geskik om die ontmensliking in die samelewing te deurbreek en gelowiges in Christus saam te bind. Die afgrensing van 'n spesialis se samelewing kan op hierdie wyse deurbreek word. ' $n$ Volgende oorweging ten gunste van die strukturering van die gemeente in die woongebied, is die belang van die verbondsgedagte in die Bybel - daarom lê die kern van die gemeente rondom die familie en gesin. Binne die woongebied, soos in die parogiale struktuur, kry ons die enigste moontlikheid waar die gesin bedien word. Wanneer die empiriese beeld en die teologiese gegewens teen mekaar opgeweeg word, is dit duidelik dat die parogie 'n struktuur bied wat nie elders vervul kan word nie. 
Dit impliseer nie dat die voordele van die kategoriale struktuur geïgnoreer moet word nie. Die kategoriale benadering hou die voordeel in dat die bediening ook die ander sektore van die leefwêreld van die lidmaat kan binnedring. Met meer vloeibaarheid kan die twee middele met mekaar gekombineer word, sodat binne die parogiale opset, ruimte geskep word vir kategoriale groepe binne en selfs oor gemeentegrense heen.

\subsection{Die herdermodel versus die liggaammodel}

In die Bybel word verskillende metafore gebruik om die wese en werking van die kerk te illustreer, byvoorbeeld die wynstok, liggaam en die kudde. Elke metafoor lê klem op 'n bepaalde aspek van die lewe en werk van die kerk. Die herder-kuddemetafoor beklemtoon die verantwoordelikheid, gesindheid en taak van die pastor teenoor die gemeente. Die liggaambeeld aksentueer weer die verantwoordelikheid van elke lid van die liggaam of kerk. Beide metafore is van belang vir die welwees van die kerk. Tradisioneel het die kerk die aksent gelê op die herder-kuddemodel, wat eensydighede tot gevolg gehad het.

\subsubsection{Die herder-kuddemodel}

Die herderbeeldspraak is uiters bruikbaar om die verantwoordelikheid van die pastor as herder teenoor die gemeente as kudde te illustreer (Dreyer 1981: 16; De Klerk 1978: 2-3). Dit is 'n metafoor wat beide in die Ou en Nuwe Testament voorkom en die bewoënheid, liefde en sorg van die herder vir sy kudde beklemtoon. Dit is ook die beeldspraak wat in die bevestigingsformulier vir die Bedienaars van die Woord gebruik word om die verantwoordelikheid en taak van die predikant mee te beskryf. Die begrip 'pastoraat' of 'herderlike sorg' word ryklik gebruik in die kerkwet om die werksaamhede van die predikant mee te beskryf. Dit is dus duidelik dat hierdie metafoor by uitstek in die kerklike taal en gebruike inslag gevind het. Die metafoor van die liggaam is verwaarloos en dit het gelei tot die eensydige aksentuering van die werk van die predikant.

Heyns (1986: 115-141) bespreek die voor- en nadele verbonde aan die herdermodel wat die kerklike lewe oorheers. Die herdermodel beklemtoon die feit dat die gemeente sy verantwoordelikheid is, soos uitgedruk in die bevestigingsformulier. 
Want net soos die werk van 'n gewone herder is om aan die kudde wat aan hom toevertrou is, weiding te verskaf, dit te lei, te beskerm en te regeer, so is dit ook met hierdie geestelike herders ....

Heyns (1986: 116) stel dan ook dat die feit dat die herder as leier voorgestel word binne die gemeente, in die tradisionele plattelandse gemeenskap ook teweeggebring het dat hy as leier in die samelewing erken en aanvaar is. Veral op die terrein van die onderwys en maatskaplike dienste het predikante diens van onskatbare waarde gelewer. In 'n sekere tyd en situasie was die herder-kuddemodel die mees doeltreffende.

'Hierdie model se krag is egter tegelyk sy swakheid. Die patriargale herder word alte maklik 'n outokraat en die gehoorsame volg van die kudde lei dikwels tot passiwiteit' (Heyns 1986: 116). Al wou die pastor dit nie wees nie, het die gemeenskap van hom die verwagting gekoester van ' $n$ leier en gesagsfiguur. Dit het in baie gevalle daartoe gelei dat hy slaaf geword het van die gemeente, die gemeenskap en struktuur. Sy gemeenskapsdiens en leiersfunksie kan ook daartoe lei dat sy eintlike bediening afgeskeep word. Die rolverwagting wat die gemeente koester vanuit die herdermodel, het meegebring dat hy hoofsaaklik alleen vir die versorging van die kudde verantwoordelik was, wat weer op sy beurt 'n oorwaardering van die predikant en 'n onderwaardering van die lidmaat tot gevolg gehad het. Daarom kwyn gemeentes tydens vakantskappe. Die kudde het totaal van die herder afhanklik geword en die amp van die gelowige het nie meer gefunksioneer nie.

\subsubsection{Die liggaammodel}

Die metafoor van die kerk as liggaam van Christus beklemtoon die betrokkenheid, verantwoordelikheid en gawes van elke afsonderlike lidmaat. Hierdie metafoor moet nie afgespeel word teen dié van die herder asof dit sou neerkom op 'n keuse tussen die twee nie. Die twee metafore moet naas mekaar geplaas word om 'n meer volledige beeld van die gemeente te kry. Die een sluit die ander nie uit nie, maar vul dit juis aan.

In die liggaambeeld kom die amp van elke gelowige na vore, wat in die kerklike praktyk verwaarloos is. Die bevestigingsformulier toon dit duidelik waar die beeld van Efesiërs 4: 11 gebruik word om die instelling van die herdersamp te motiveer, terwyl die amp as toerusting van gelowiges tot opbou van die liggaam verwaarloos word. 
Indikatore vir die liggaam-van-Christus-model sou wees dat die pastor hom as begeleier sien wat veral die taak het van lidmate te onderrig sodat die gemeente tot selfstandigheid sal kom, die gemeente die pastor as gespesialiseerde werker aanvaar en benut, maar dat hulle self vir die opbou van die gemeente verantwoordelik is ... (Heyns 1986: 136).

Verder word beklemtoon dat hierdie model ook die ruimte bied vir lidmate om op grond van hulle gawes betrokke te raak by gemeentelike aktiwiteite. Dit bied die predikant die ruimte om te delegeer en in ' $n$ spanbenadering ook van ander kundiges in die gemeente gebruik te maak. Hierdie toerusting en aktivering van lidmate moet veral geskied via groepe, omdat dit ook die ideale ruimte bied vir koínōnía (Louw 1980: 167-172; Hendriks 1986: 72-85). Daar sal dus 'n meer ewewigtige aksent geplaas moet word op die predikant as herder en leraar, waarin laasgenoemde dan dui op sy toerusting- en onderrigfunksie. Dit sal ook ' $n$ verandering teweegbring ten opsigte van die leierskapstyl van die predikant. Roberts (1987: 83-90) beskryf dit as 'n verskuiwing van 'n 'unilateral' na 'n 'relational' tipe van gesagsuitoefening en styl.

\subsubsection{Evaluering}

Die leemtes as gevolg van die oorbeklemtoning van die herdermodel word hier duidelik blootgelê, asook die betekenis van die liggaammodel. Die wil lyk asof die kerk in sy bedieningstrukture meer reg sal moet laat geskied aan die liggaammodel. Dit sal egter 'n geleidelike oorgang moet wees omdat gemeentes nog leef in die verwagting van die herdermodel. Die rolverwagting ten opsigte van die predikant sal eers nader gedefinieer en gekorrigeer moet word in die gemeentelike lewe. Lidmate sal opgevoed en toegerus moet word om hulle verantwoordelikheid te aanvaar.

\subsection{Diakonale bedieningstruktuur}

As moontlike nuwe aksente in bedieningstrukture word in sommige kringe gedink vanuit die perspektief van die diakonaat. Die gerigtheid van 'n diakonale gemeente is om betrokke te raak by die nood van mense. 'Overal waar mensen in hun leven en samenleven worden bedreigd, is de gemeente geroepen tot dienst' (De Jonge 1986: 296). Hier raak die lidmaat betrokke by diakonale aksies '... meer diakonaal 
werken, dan diakonaal bezinnen' (De Jonge 1986: 300). Prediking, kategese en pastoraat word diakonaal afgestem.

Diakonale aksies slaag gewoonlik daarin om mense betrokke te kry omdat dit veel meer geleentheid bied tot aktiewe deelname. Diakonaat is ' $n$ onontbeerlike deel van die kerklike bediening, maar wanneer dit verhef word tot die middelpunt van die kerklike bediening, lei dit noodwendig tot ' $n$ teologiese en kerklike wanbalans. Die positiewe van die diakonale perspektief lê daarin dat dit aan lidmate oor 'n wye terrein geleentheid bied om betrokke te raak by wyse van diakonale diensgroepe.

\subsection{Charismatiese bedieningstrukture}

Onder hierdie noemer kan ' $n$ hele aantal modelle in die meer charismatiese kringe tuisgebring word. Hierdie strukture is veral gepopulariseer vanuit die Amerikaanse wêreld en literatuur. 'n Menigte van hierdie modelle word aangebied wat elkeen weer'n ander aksent lê. As algemene kenmerke geld die volgende:

- anti-institusionalisme, gerig teen die georganiseerde en gevestigde kerke;

- 'n losse kerkorganisasie;

- huisgemeentes;

- beklemtoning van die leke-bediening teenoor die ampte;

- gebruikmaking van kleingroepe as middel tot 'fellowship';

- dissipels maak dissipels;

- sterk evangelisasiegerigtheid;

- skoling en toerusting.

Getz (1984: 15-30) gee 'n oorsig van die verskillende fases en beskouings. Daar word nie verdere aandag aan hierdie modelle gewy nie, omdat die positiewe aspekte wat in sommige van die modelle voorkom, reeds in vorige modelle opgevang is.

\subsection{Tentmakerbediening}

Teenswoordig word steeds meer stemme gehoor ten gunste van die tentmakerbediening, veral vanuit die missionêre perspektief van groeiende gemeentes. Die finansiële implikasies van die onderhoud van 'n voltydse predikantstandplaas maak dit vir jong kerke en gemeentes onmoontlik om selfstandig te word (Stapelberg 1987: 5). Kritzinger 
(1979: 182-86) bepleit ook die herwaardering van die tentmakerbediening wat in die Westerse kerke in onbruik geraak het.

Die finansiële eise van ons tyd, wat ook geld ten opsigte van die kerk, mak dit dikwels vir gemeentes met 'n voltydse predikantstandplaas moeilik om te oorleef. In hierdie verband kan die tentmakerbediening moontlik 'n oplossing bied. Die ooraanbod van afgestudeerde predikante wat nie beroepe kry nie, bring vanuit 'n ander perspektief die tentmakerbediening onder die soeklig. Kan die kerk nie van hierdie beskikbare kragte gebruikmaak, sonder dat hulle noodwendig voltyds in die bediening hoef te staan nie?

Daar is reeds aangetoon dat geen teologiese besware teen die tentmakerbediening ingebring kan word nie. Dit blyk dus 'n betekenisvolle moontlikheid te wees in die oorweging van toekomstige bedieningstrukture.

\subsection{Samevatting}

As daar vanuit ' $n$ beoordeling van die verskillende modelle vir bedieningstrukture 'n samevatting gemaak word, kan die volgende positiewe aspekte binne die opset van 'n reformatoriese kerk geakkommodeer word.

- 'n Rigiede en stereotipe bedieningspatroon sal moet plek maak vir 'n meer vloeibare patroon wat rekening hou met die situasie van elke gemeente.

- Kategoriale bediening kan plaasvind waar homogene groepe saamwoon. Binne territoriale gemeentes sal binne gemeenteverband ruimte geskep moet word vir kategoriale groepe.

- Die liggaammodel sal naas die herdermodel die verantwoordelikheid van elke lidmaat moet beklemtoon.

- Die aksent moet verskuif na die predikant as toeruster.

- Groepe sal binne gemeentelike opset gebruik moet word as middel tot toerusting, bespreking en taakvervulling.

- Delegering en ontginning van die potensiaal van lidmate sal prominent na vore moet kom.

- Die tentmakerbediening kan as aanvulling by die voltydse bediening geïmplementeer word.

- Die taak en rol van die predikant sal nader gedefinieer moet word.

- Die rolverwagting van die predikant sal by die gemeente dienooreenkomstig gekorrigeer moet word.

- 'n Relasionele leierskapstyl sal moet posvat. 
- Die oorgang sal geleidelik moet geskied.

- Soepelheid vir die implementering van spesialisasie en bearbeiding oor gemeentegrense heen.

\section{POGING TOT 'N EIE MODEL}

In die lig van die voorafgaande kan, met inagneming van die resultate van die ondersoek, gepoog word om 'n eie model vir ' $n$ bedieningstruktuur daar te stel. Die uitgangspunt vir so 'n model sou wees dat daar wegbeweeg word van 'n rigiede patroon na groter soepelheid waar die patroon aangepas kan word na gelang van die plaaslike omstandighede. Tegelyk moet die eensydige aksent van die predikant as herder geleidelik meer gebalanseerd geplaas word op die predikant as herder en leraar (toeruster). Dit sal die ruimte en geleentheid bied vir die lidmaat om sy verantwoordelikheid beter te vervul.

Daar sal eerstens 'n duideliker omskrywing gegee moet word van die spesifieke taak van die predikant met die moontlikheid vir aanpassings en klemverskuiwing na gelang van plaaslike omstandighede. Hierdie taakomskrywing kan tegelyk ook dien as korrigering vir die rolverwagting wat die gemeente van die predikant koester.

\subsection{Taakomskrywing van die predikant}

In die huidige struktuur binne die Hervormde Kerk is die taakomskrywing vaag en ongedefinieerd. Sekere take word amptelik aan die predikant opgedra as uitsluitlik sy verantwoordelikheid. 'n Ander kategorie verpligtinge word gesamentlik opgedra aan die predikant en ouderlinge. 'n Derde kategorie verpligtinge word nêrens amptelik aan hom toegewys nie, maar word tog van hom verwag.

\subsubsection{Take wat spesifiek aan die predikant opgedra word}

Bepaling 149.1 van die Kerkwet (NHK 1986) handel oor die gemeentelike dienswerk van die predikant en spel 'n aantal verantwoordelikhede uit, wat soos volg saamgegroepeer kan word.

- Verkondiging van die Woord, wat hier eintlik verstaan moet word as prediking, omdat die ander gestaltes van die verkondiging later afsonderlik aangedui word.

- Liturgiese verantwoordelikheid, wat insluit die bediening van sakramente, lei van eredienste, voorbidding, bevestiging van ampsdraers, 
afneem van openbare belydenis van geloof, bevestiging van huwelike en lei van begrafnisdienste.

- Pastorale versorging van die gemeente, wat aangedui word as voorbidding en vertroosting.

- Bestuursverantwoordelikheid, naamlik die lei van vergaderings.

Hieruit blyk duidelik hoe vaag die omskrywing is. Die pastoraat wat 'n groot deel van die predikant se tyd in beslag neem, word nie nader gepresiseer as bloot die vertroosting van bedroefdes en voorbidding nie. Die hele spektrum van die besondere pastoraat word nêrens verdiskonteer nie. Die bestuursverantwoordelikheid van die predikant word bloot aangedui as die lei van vergaderings. Hierdie verantwoordelikheid word nêrens omlyn nie en kan in praktyk beteken dat hy voorsitter van elke moontlike vergadering word.

\subsubsection{Take wat die gesamentlike verantwoordelikheid van die predikant en ouderling is}

Bepaling 149.2 (NHK 1986) bepaal hierdie gesamentlike verantwoordelikheid as:

- herderlike sorg

- evangelisasie

- kategese

- geestelike vorming van die jeug

- opsig, toesig en tug.

Hier is weer eens geen sprake van 'n omlyning van die taakverdeling tussen ouderling en predikant nie. Dit skep die moontlikheid vir wat inderdaad dikwels in die praktyk plaasvind, naamlik dat genoemde sake grotendeels die verantwoordelikheid van die predikant word. Vanuit verskillende rade is daar pogings om byvoorbeeld ten opsigte van kategese en evangelisasie, die taakomlyning van predikant, ouderling en diaken duideliker af te grens. Oorkoepelende beplanning ontbreek egter nog.

Dit is opmerklik dat die huisbesoektaak van die predikant verder omskryf word onder die bepalings van die opsig, waar in Bepaling 101.3 gestel word dat die predikant jaarliks by elke gemeentelid huisbesoek moet doen. Die huisbesoek word dus nie onder die pastoraat wat die verantwoordelikheid van die predikant is, tuisgebring nie, maar by die opsig wat primêr die taak is van die ouderling. Die praktyk van huisbesoek in die kerk lê dus tydgewys die grootste klem op die 
predikant as opsighouer, in plaas van op sy hoedanigheid as herder en leraar (toeruster).

\subsubsection{Take wat nie-amptelik verwag word}

Behalwe die genoemde verantwoordelikhede wat in die Kerkwet aangedui word, is daar talle funksies wat 'nie-amptelik' aan die predikant opgedra word waarvan die predikant hom nie kan losmaak nie, omdat sy oorlewing binne die rolverwagting van die gemeente hom daartoe dwing. Sekere opdragte word in die Kerkwet genoem sonder om dit aan 'n bepaalde persoon toe te wys, byvoorbeeld die praktyk van doopkategese, soos vermeld in Bepaling 87.3. 'Die Kerkraad sorg daarvoor dat die predikant of ouderlinge wat daarvoor benoem is, al die doopouers onderrig oor die betekenis van die doop.' Dieselfde geld ten opsigte van die huwelikskategese. In albei gevalle kom dit in praktyk daarop neer dat dit die taak van die predikante is. Vanuit verskillende rade word daar in die afgelope tyd 'n magdom take en verantwoordelikhede uitgedeel. Hierdie rade werk vanuit die denkmodel van die liggaammetafoor waarin veronderstel word dat lidmate hierdie take kan en sal uitvoer. Die praktyk bewys egter dat ons so vasgevang is in die herdermodel dat in baie gevalle dit in praktyk daarop neerkom dat dit die verantwoordelikheid van die predikant word. As hierdie 'nieamptelike' take van die predikant neergeskryf word, verander die prentjie aansienlik. Die volgende kan hieronder genoem word:

- Huweliks- en doopkategese.

- Toerusting van kerkraad.

- Toerusting en organisasie van diensgroepe.

- Toerusting van kategete.

- Evangelisasiekursusse en -skoling.

- Bybelstudie.

- Sinodale verantwoordelikhede en kommissiewerk.

- Organisatoriese verantwoordelikhede op gemeentelike vlak.

Die predikant moet oorleef binne die rolverwagting van die herdermodel wat die geldende is. Hy word 'n klomp take toegewys vanuit die liggaammodel, wat in praktyk beteken dat hy dit moet doen. In hierdie dilemma is predikante vasgevang, hulle raak gefrustreerd en dit lei tot 'n oppervlakkige bediening om almal tevrede te stel. In die taakomskrywing van die predikant sal daar die soepelheid moet wees om die oorgang van die een model na die ander moontlik te maak.

As daar ook aanvaar word dat die predikant hom voortdurend verder 
moet bekwaam deur sy voortgesette teologiese studie, sal dit as opdrag amptelik erken moet word en in sy beplanning verdiskonteer word. Hierdie 'nie-amptelike' take sal ook geëvalueer en gedefinieer moet word en in berekening gebring word by die omlyning van sy opdrag.

\subsubsection{Huisbesoek en pastoraat}

Omdat die huisbesoektaak soveel prominensie geniet in ons huidige bedieningstruktuur en feitlik die hele pastoraat opslurp, verdien dit afsonderlike aandag.

Muller (1985: 311) toon aan dat die gelykstelling van pastoraat en huisbesoek spruit uit die toepassing van die herder-kuddemodel op die klein landelike gemeente. Hier kan die een herder sy kudde doeltreffend versorg deur gereeld by hulle aan huis te kom. In die moderne groot stedelike gemeente is dit net nie meer moontlik nie. Vanuit hierdie herdermodel stel lidmate ook 'n hoë verwagting aan die gereelde huisbesoek van die predikant.

Soos reeds aangetoon, word binne die Hervormde Kerk die huisbesoek tuisgebring onder die opsig. Die opsigtaak is primêr die verantwoordelikheid van die ouderling. Die ouderling vorm die eerste linie van die opsigtaak en daarom is dit nodig dat sy besoeke aan lidmate 'n hoë frekwensie sal handhaaf. Die predikant se opsigtaak lê in die tweede linie, waar die klem nie soseer lê op kontrole nie, maar op die remediërende of terapeutiese faset. Hy moet dus vanuit sy teologiese opleiding remediërend toetree op grond van probleme wat uitgewys is deur die eerste linie van opsig deur die ouderling. Dit maak die huisbesoek van die predikant nie oorbodig nie, maar verminder die frekwensie en verleen daaraan ' $n$ ander inhoud en aksent.

Huisbesoek by alle lidmate is noodsaaklik om 'n gesonde pastorale relasie tussen pastor en lidmaat te skep. Dit skep die geleentheid om die Woord te bring binne die konkrete, toegespitse situasie van die huisgesin. Dit bied ook aan die predikant die geleentheid om postkategeties voorkomend te werk. Individuele huisbesoek kan ook afgewissel word met groepspastoraat, sodat by wyse van rotasie, elke lidmaat oor 'n periode van twee of drie jaar individueel besoek word. Die frekwensie van die huisbesoek deur die predikant sal in 'n groot mate bepaal word deur plaaslike omstandighede soos die aantal besoekpunte, tye beskikbaar vir huisbesoek, die voorkoms van probleme wat besondere pastorale aandag vereis, ensovoorts.

Daar moet dus meer soepelheid aan die dag gelê word sodat die kerkraad saam met die predikant, met inagneming van die situasie, die 
frekwensie van die huisbesoek kan bepaal. ' $n$ Minimum aantal besoekpunte per jaar kan as algemene voorskrif geld, byvoorbeeld dat predikante, in oorleg met die kerkraad, die huisbesoek jaarliks beplan met dien verstande dat daar ten minste by 'n honderd besoekpunte jaarliks besoek afgelê word.

Die voorkoms en omvang van die besondere pastoraat, toegespits op lidmate wat besondere probleme of krisisse ondervind, word steeds meer. Vaste spreekure sal weekliks daarvoor gereserveer moet word en dit sal in berekening gebring moet word by die oorkoepelende beplanning. Die praktyk het bewys dat die aanvraag na die besondere pastoraat toeneem hoe langer die predikant in die gemeente werksaam is en namate die vertrouensverhouding gevestig raak. Dit kan dus in praktyk beteken dat gedurende die eerste jare in 'n gemeente, die klem swaarder sal rus op die huisbesoek, terwyl die klem later sal verskuif na die besondere pastoraat. Die beplanning van die pastorale praktyk sal ook verder beïnvloed word deur plaaslike omstandighede soos die voorkoms en intensiteit van bejaardesorg en siekepastoraat.

In geheel gesien, moet die rigiede pastorale patroon met die aksent op huisbesoek meer soepel word sodat in die oorkoepelende beplanning van die taak van die predikante, daar na gelang van omstandighede aksentverskuiwings kan plaasvind.

\subsection{Komponente, tydwaardes en beplanning}

Om ' $n$ aangepaste bedieningstruktuur daar te stel met inagneming van die situasie, en tegelyk ' $n$ aksentverskuiwing te bewerkstellig van die herdermodel na die liggaammodel, is dit nodig dat die taak van die predikant omlyn sal word in terme van komponente, prioriteite en tydwaardes.

\subsubsection{Bedieningskomponente en tydwaardes}

Die totale bediening van die predikant word gevorm deur verskillende komponente, waarvan sommige amptelik en ander nie-amptelik aan hom toegesê word. Al hierdie moontlike bedieningskomponente sal geïdentifiseer moet word en dan na gelang van omstandighede in prioriteite gerangskik moet word. Aan elke bedieningskomponent sal 'n tydwaarde toegeken moet word om oorkoepelende beplanning moontlik te maak. As moontlike voorbeeld van bedieningskomponente en toegekende tydwaardes kan die volgende geld:

- Prediking - tydwaarde toegeken aan die voorbereiding van een preek is tien ure. 
- Liturgiese komponent - die tydwaarde van die lei van eredienste op Sondae word nie in berekening gebring nie, omdat dit die normale verantwoordelikheid van elke gelowige is om eredienste by te woon.

- Begrafnisdienste - die tydwaarde toegeken aan die voorbereiding van 'n preek en die tyd bestee aan die diens self kan op vier ure gestel word.

- Huweliksbevestiging - tydwaarde vir voorbereiding en bevestiging, vier ure.

- Kategese - tydwaarde vir voorbereiding en aanbieding van een les, twee ure.

- Huisbesoek - tydwaarde per besoekpunt - een uur.

- Besondere pastoraat - tydwaarde per afspraak - een uur.

- Bybelstudie - voorbereiding en aanbieding per sessie, tydwaarde twee ure.

- Siekepastoraat en bejaardesorg - tydwaarde per besoek - een uur.

- Toerustingsgeleenthede vir evangelisasie, kategete, diensgroepe, jeug ensovoorts - tydwaarde vir voorbereiding en aanbieding - drie ure per sessie.

- Lei van vergaderings - drie ure per vergadering.

- Sinodale vergaderings - drie ure per vergadering.

- Huweliks- en doopkategese - twee ure per sessie.

\subsubsection{Beplanning}

Vanuit hierdie moontlike bedieningskomponente sal elke predikant, in samewerking met sy kerkraad, met inagneming van omstandighede, sy taak moet omlyn. By die beplanning sal in gedagte gehou moet word dat die aksent verplaas moet word vanaf die herdermodel na die liggaammodel. Die kerkraad sal die situasie moet ontleed om vas te stel in hoeverre die lidmate al gereed en toegerus is, sodat verantwoordelikhede gedelegeer kan word. Indien nie, sal meer tyd ingeruim moet word vir toerusting. Die frekwensie van die besondere pastoraat, siekepastoraat en bejaardesorg sal oorweeg moet word. Die situasie sal ingrypend verskil in byvoorbeeld ' $n$ studentegemeente of ' $n$ plattelandse gemeente. As 'n evangelisasieprogram of nuwe diensgroepe van die grond af op die been gebring moet word, sal in die beplanning aanvanklik meer tyd daarvoor afgesonder moet word. Die beplanning sal ook beïnvloed word deur die hoeveelheid preke wat die predikant per week moet voorberei. Daar sal ook elke week in die beplanning ' $n$ aantal ure afgestaan moet word vir krisisse en onvoorsiene gebeure.

As 'n gemiddelde basis kan gereken word op 45 werksure per week 
wat nog ruim tyd toelaat vir ontspanning. Die vaste komponente moet eers per week bereken word, byvoorbeeld:

Preekvoorbereiding - 2 preke, 20 uur.

Kategese -1 les, 2 uur.

Afsprake vir besondere pastoraat -6 uur.

Siekebesoek - 6 uur.

Jeugbyeenkoms -3 uur.

Vergadering -3 uur.

Bybelstudie -1 uur.

Totaal $=41$ uur per week.

Volgens hierdie voorbeeld van beplanning bly vier ure oor vir huisbesoek, wat dus vier besoekpunte per week sou beteken, maal veertig aktiewe weke per jaar sou dus neerkom op honderd en sestig besoekpunte per jaar. Indien die kerkraad meer toerustingsgeleenthede wil hê, sal dienooreenkomstig die tyd afgesonder vir besondere pastoraat of Bybelstudie, verminder moet word. In gemeentes waar minder siekebesoek gedoen of slegs een preek voorberei moet word, sal die prentjie anders lyk. Hierdie beplanning kan op 'n maandelikse basis geëvalueer en aangepas word.

Vanuit die beplanning van die verskillende komponente van die bediening, het die predikant dan die vryheid om sy werksprogram te skeduleer na goeddunke. Dit laat hom die vryheid om binne die breë raamwerk sy eie tydindeling te maak. 'n Voorbeeld van so 'n geskeduleerde werksprogram kan as volg daar uitsien.

\subsubsection{Skedulering van werkprogram}

\begin{tabular}{|c|c|c|c|}
\hline Dae & $\begin{array}{l}08 \mathrm{~h} 00-13 \mathrm{~h} 00 \\
(5 \text { uur) }\end{array}$ & $\begin{array}{l}\text { 15h00-17h00 } \\
\text { ( } 2 \text { uur) }\end{array}$ & $\begin{array}{l}19 \mathrm{~h} 00-22 \mathrm{~h} 00 \\
\text { ( } 3 \text { uur) }\end{array}$ \\
\hline Maandag & Vrye tyd & Vrye tyd & Vrye tyd \\
\hline Dinsdag & Preekvoorbereiding & $\begin{array}{l}\text { Huisbesoek }(2 \times 1 \\
\text { uur besoekpunte })\end{array}$ & $\begin{array}{l}\text { Huisbesoek }(3 \times \\
1 \text { uur besoek- } \\
\text { punte })\end{array}$ \\
\hline$\overline{\text { Woensdag }}$ & Siekebesoek & $\begin{array}{l}\text { Besondere pastoraat } \\
(2 \times 1 \text { uur afsprake })\end{array}$ & $\begin{array}{l}\text { Besondere }(3 \times 1 \\
\text { uur afsprake })\end{array}$ \\
\hline$\overline{\text { Donderdag }}$ & Preekvoorbereiding & $\begin{array}{l}\text { Bybelstudie (1 uur) } \\
\text { Kategese (1 uur) }\end{array}$ & Vergadering \\
\hline$\overline{\text { Vrydag }}$ & Preekvoorbereiding & $\begin{array}{l}\text { Siekebesoek } \\
\text { (Krisisse) }\end{array}$ & $\begin{array}{l}\text { Onvoorsiene } \\
\text { (Reserwe) }\end{array}$ \\
\hline Saterdag & Preekvoorbereiding & & \\
\hline
\end{tabular}

* Moontlike werksure $=55$ uur per week. 
Vaste komponente

Preekvoorbereiding 20 uur

Besondere pastoraat 5 uur

Kategese 1 uur

Huisbesoek 5 uur

31 uur

Wisselende komponente

Siekebesoek 7 uur

Bybelstudie 1 uur

Vergadering 3 uur

Onvoorsiene 3 uur

14 uur

TOTAAL $\overline{45 \mathrm{uur}}$

In so 'n taakomlyning wat opgebou word uit verskillende komponente, word ook die moontlikheid gelaat dat komponente tussen predikante binne ringsverband afgewissel en uitgeruil kan word. Die superintendent vir evangelisasie of kategese kan dus binne ringsverband aan al die gemeentes toerusting verskaf, mits daar in ringsverband weer in tydwaarde vergoed word; ander predikante kan byvoorbeeld sommige preekbeurte waarneem. Vanuit die perspektief van die tentmakerbediening kan beskikbare kragte met sekere komponente belas word, wat weer aan die plaaslike predikant meer tyd gee vir ander komponente.

In hierdie beplanningsaksie word die ouderlinge of ' $n$ werkgroep betrek, wat voortdurend die predikant help beplan en evalueer. Hierdie beplanning moet van tyd tot tyd ook aan die gemeente deurgegee word, wat weer korrigerend sal inwerk op die rolverwagting wat hulle van die predikant koester.

Die ringsrade vir predikante kan 'n belangrike bydrae lewer om sinvolle beplanning en koördinering binne ringsverband te bewerkstellig.

\section{SLOTOPMERKING}

Met hierdie oefening is gepoog om weg te beweeg van 'n vaste bedieningspatroon wat geld vir alle omstandighede. Eers wanneer die nodige soepelheid in bedieningspatrone bestaan, kan geleidelike ak- 
sentverskuiwings plaasvind. Dan kan daar tyd geskep word vir die toerusting en implementering van kategoriale groepe. Deur groepwerk en toerusting kan lidmate geskool word om hulle verantwoordelikheid van die bediening te aanvaar. Uiteindelik sal die predikant kan begin delegeer en sal die kerk wegbeweeg van 'n leierskapstyl waarin die predikant die enigste leier en gesagsfiguur is. In sommige gemeentes sal die proses vinniger verloop as by ander, maar juis daarvoor moet daar ruimte en begrip wees.

So sal ons uiteindelik almal kom tot die werklike eenheid in ons geloof en in ons kennis van die Seun van God. Dan sal ons, sy kerk, soos 'n volgroeide mens wees, so volmaak en volwasse soos Christus ... Die verskillende liggaamsdele pas bymekaar en vorm saam 'n eenheid. Elkeen van hulle vervul sy funksie en so bou die liggaam homself op in liefde (Ef 4: 13 en 16).

\section{Literatuurverwysings}

ALANT, CJ 1972. ' $n$ Sosiologiese studie van die betrokkenheid van lidmate by die Nederduits Gereformeerde Kerk. Pretoria: CJ Alant.

BOLKESTEIN, MH 1961. Het gemeentelid, zijn plaats en roeping volgens het Nieuwe Testamant. Driebergen: Kerk en Wêreld (Horstcahiers nr 14.)

COX, H 1968. De stad van de mens. Sewende druk. Utrecht: Ambo.

DEKKER, G 1975. Wat is er met de kerk aan de hand? Tweede druk. Baarn: Ambo.

DE JONGE, KT 1986. Diakonaat en gemeente. Theologia Reformata 29, 3.

DE KLERK, JJ 1978. Herderkunde. Pretoria: NG Kerkboekhandel.

DREYER, TFJ 1981. Poimeniek - 'n pastorale oriëntasie. Pretoria: Kital.

GETZ, A 1984. Sharpening the focus of the church. Illinois: Victor.

GREIMACHER, N 1966. Die Kirche in der städtischer Gesellschaft. Mainz: MatthiasGrünewald.

HEITINK, G 1979. Pastoraat als hulpverlening. 2de druk. Kampen: Kok.

HENDRIKS, J 1986. Vernuwing in die bedieningstruktuur. NGTT 27, 1.

HEYNS, L 1986. Studiegids Unisa. PTB $302-\mathrm{A} / 1$.

HOEKENDIJK, JC 1965. Die kerk binneste buiten. Amsterdam: Ten Have.

KRITZINGER, JJ 1979. ' $n$ Missionêre bediening - op weg na strukture vir'n jong kerk. Pretoria: NG Kerkboekhandel.

LOUW, DJ 1980. Die stad in die mens. Pretoria: NG Kerkboekhandel.

MULLER, JC 1985. Huisbesoek te midde van veranderde omstandighede. NGTT 26, $311-318$.

Nederduitsch Hervormde Kerk van Afrika. Algemene Kerkvergadering 1985. Kerk en Wêreld 2000 . Pretoria: Kital.

Nederduitsch Hervormde Kerk van Afrika. Algemene Kerkvergadering 1986. Kerkwet en Bepalings. Pretoria: NHW-Pers.

PIETERSE, HJC 1981. Bedieningstrukture. Die Kerk se werk. Kongresreferate van die Werkgemeenskap vir Praktiese Teologie 1981-1982. Pretoria: Werkgemeenskap vir Praktiese Teologie.

PIETERSE, HJC 1985. Verwoording en prediking. Pretoria: NG Kerkboekhandel.

ROBERTS, JH 1963. Die opbou van die Kerk volgens die Efese-brief. Groningen: VRB. 
ROBERTS, B 1987. Power and servanthood. Emerging notions for church leadership. Encounter 48,1.

STAPELBERG, JPM 1987. Nuwe bedieningspatroon is nodig in familie van NG Kerke. Die Kerkbode 139, Maart 1987, bl 5.

VISCHER, L 1965. The ministry and a secular occupation, in Paton (ed), New Forms of Ministry, 36-54.

WOLFAARDT, JA 1971. Kerklike konfrontasieoorde. Groningen: JA Wolfaardt. 